\title{
Preference Learning Style in Engineering Mathematics: Students Perception of E-Learning
}

\author{
Norngainy Mohd Tawil ${ }^{1,2}$, Nur Arzilah Ismail ${ }^{1,2}$, Izamarlina Asshaari ${ }^{1,2}$, Haliza Othman ${ }^{1,2}$, Azami Zaharim ${ }^{1} \&$ \\ Hafizah Bahaludin ${ }^{2}$ \\ ${ }^{1}$ Centre for Engineering Education Research, Faculty of Engineering and Built Environment, Universiti \\ Kebangsaan Malaysia, Selangor, Malaysia \\ ${ }^{2}$ Unit Fundamental Engineering Studies, Faculty of Engineering and Built Environment, Universiti Kebangsaan \\ Malaysia, Selangor, Malaysia \\ Correspondence: Norngainy Mohd Tawil, Unit Fundamental Engineering Studies, Faculty of Engineering and \\ Built Environment, Universiti Kebangsaan Malaysia, 43600 UKM Bangi, Selangor, Malaysia. Tel: \\ 60-389-216-691. E-mail: nmtawil@gmail.com
}

Received: February 7, 2013 Accepted: April 7, 2013 Online Published: May 13, 2013

doi:10.5539/ies.v6n6p61

URL: http://dx.doi.org/10.5539/ies.v6n6p61

\begin{abstract}
Nowadays, traditional learning styles are assisted with e-learning components to ensure the effectiveness the teaching and learning process especially for the students. This approach is known as blended learning. Objective of this paper is to investigate and clarify the students' preferences in learning style either traditional or e-learning. Specifically, traditional learning styles fall into two group which are by individual or by group. The sample of this study consists of 189 First Year engineering students at the Faculty of Engineering and Built Environment UKM who have taken Mathematics as their core courses. This study revealed that students are preferred to study in traditional learning styles compared to e-learning. Also, individual learning styles is the most favourable.
\end{abstract}

Keywords: engineering mathematics, e-learning, learning style

\section{Introducation}

\subsection{The Importance of Blended Learning}

As we enter the third millennium, education via the internet, intranet or network represents great and exciting opportunities for both educators and learners. Educators have witnessed the rapid development of computer networks and improvement in the processing power of personal computers. Even though educators and learners strongly admit that traditional teaching has their important role in teaching function (Mandic, 2010) but we cannot avoid the development in Information and Communication Technologies (ICT). Due of this reason, blended learning has been introduced in educational system to give positive consequences especially to the students. Blended learning is a composition of traditional types of learning and e-learning.

According to Hisham, et al. (2006), blended learning define as the integrated combination of traditional learning with web based online approaches, the combination of media and tools deployed in e-learning environment and the combination of number of pedagogical approaches. Implementation of blended learning is to bring together the strengths and overcome the weakness either in traditional method or e-learning (Azizan, 2010). In view of that, the application of blended instruction has quickly increased because instructors believe that varied delivery methods can increase students' satisfaction from the learning experience as well as their learning outcomes. However, e-learning can be viewed in different perspectives. First, it believes that any teaching and learning process that assisted with any form of technology can be considered as e-learning. On other hand, it claims that e-learning is the alternative for the distance education which facilitated by internet as a form of communication. This research strongly insists that we considered e-learning as first case that stated above. Nevertheless, lecturing was significantly of importance and favourable in the learning process for statistics and mathematics courses compared to the newly-introduced WILEY PLUS (Tawil et al., 2012). Whereas, Che Ani et al. (2012) found that The findings from the study reveals, in principal the students agree to use the portal, with the lecturer observing the usage of the system in portal via progress monitoring report and correlate the total time, numbers of visit and page hits of the students. 


\subsection{E-Learning as Tools for Better Understanding in Engineering Mathematics}

The conceptions, attitudes, and expectations of the students regarding mathematics and mathematics teaching have been considered to be very significant factor underlying their school experience and achievement (Borasi, 1990). This fact also supported by Yushau (2006) that students experience difficulties in studying Mathematics since they have to understand the theories and rememorize the formulae. Based on this reason, Faculty of Engineering and Built Environment (FKAB) implemented e-learning system known as WILEY-PLUS to assist students as well as lecturers to get effective teaching and learning process. Wiley-plus is a web based application that assists instructor in preparing for classes and lectures and automates the process of assigning and grading homework. As a result, students like and satisfied about the idea of blended learning (integrated traditional learning with Wiley-Plus) that implemented in mathematics courses (Razali et al., 2010). In order to be parallel with young generations in terms of technology, e-learning was introduced to engineering students in FKAB with the hope that e-learning is a way to enhance learning in a more convenience and cost-effective manner (Tawil et al., 2012).

As far as we concern, students adapted the concept of blended learning. However, adapted the concept of blended learning is not prove that students can accept the concept wholeheartedly. Could be e-learning has same priority with the traditional learning style in students' view? Therefore, the objective of this research is to investigate and clarify the students' preferences in learning style either traditional or e-learning. The traditional learning style can be categorized into individual (read text or reference book; read lecture notes; read their own exercises and group learning style (discussion with friends, asked tutor or lecture). Albano and Ferrari (2008) has overcome the current separation between technology and educational research, as their joint use can provide matchless opportunities for dealing with most of the learning problems related to mathematical concepts as well as to linguistic, metacognitive, and noncognitive factors. Meanwhile, e-learning can be defined using mathematical applications in the Wiley-PLUS or using any web sites related to mathematics.

In evaluating the students achievement, e-learning can beneficial to the students and the lecturers as well since both parties can monitor the achievement at anytime and anywhere which give the students chance to test their ability and understanding as much as they want. This research has been done by Rasila et al. (2010) with the results of their experiences have shown that e-assessment is suitable for large scale teaching of engineering mathematics, it does not lead to overwhelming technical problems, and it can be highly motivating for the students. Besides these benefits, the system may lead to cost savings, at least in the long run.as also mentioned by David et al. (2010) that the applications in mathematics e-learning indicate both present and potential uses for this software as a basis for eLearning applications in Science, Technology, Engineering and Mathematics through the addition of suitable pedagogies. Pais et al. (2004) doing research in e-learning found that this solution involves the assistance of computers working as pedagogical tools complementary to the traditional methods that are used in the teaching of subjects such as Mathematics, Electrics and Electronics can help the students focus and understand more in other subject.

Bringslid (2002) mentioned that the improvement of understanding mathematics by using interactive and personalized documents on the Web could reverse bad trends, and the problems associated with recruiting girls into engineering and mathematics also have to be emphasized through the selection of applications. With ICT, students can get more information and examples to help them to understand mathematics. With better understanding in mathematics the students can apply in engineering subjects (Tawil et al., 2010). In 2005, Albano conclude that, many interesting starting points have been arisen from the described beginning investigations and planned to use them as basis for further inquiries and more intensive and suitable activities in blended learning..

\section{Method}

\subsection{Participants}

Questionnaires were given to the first year students from academic session 2011/2012 at Faculty of Engineering and Built Environment (FKAB), UKM. A total number of 189 students are involved in this study with 42 students from Civil \& Structure Engineering (JKAS), 68 students from Mechanical \& Material Engineering (JKMB), 25 students from Chemistry\& Process Engineering (JKKP) and 54 students from Electric, Electronics $\&$ System Engineering (JKEES). The percentage of the students based on their gender as depicted in Figure 1. It shows that 55 percents of the students are male whereas the others are female students. 


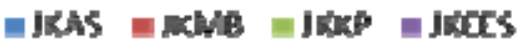

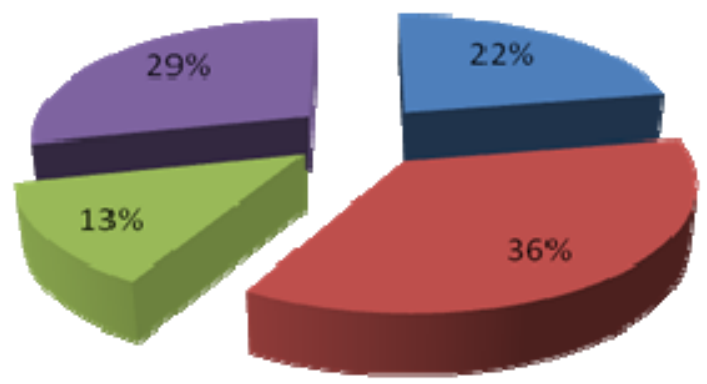

Figure 1. Percentage of the students based on the departments in FKAB

\subsection{Instruments}

Scope of the questionnaire was about their perception on learning style specifically. The instrument used in this study was the survey that has two parts which are student profile and students' perception of learning style. At each question the students are required to mark using the Likert scale of 1 to 10 . Mark as 1 for most important and mark as 10 for least important with the given statements.

This study utilized the data gathered by the survey instruments to answer the research questions. The data obtained from the returned surveys were analyzed, and responses to the research questions were made using simple statistical method to analyze level of important on each attribute.

\section{Results and Discussion}

First and foremost, students' exposure or experience toward internet has been evaluated. The reason of this attribute is to ensure that early of assumption towards students is true. Researchers assume that half of the students were familiar with the internet more than two years. As we know, e-learning requires students well known using internet. Result indicates that the assumption is true which 65 percents of students experience using internet more than four years as shown in Figure 2.

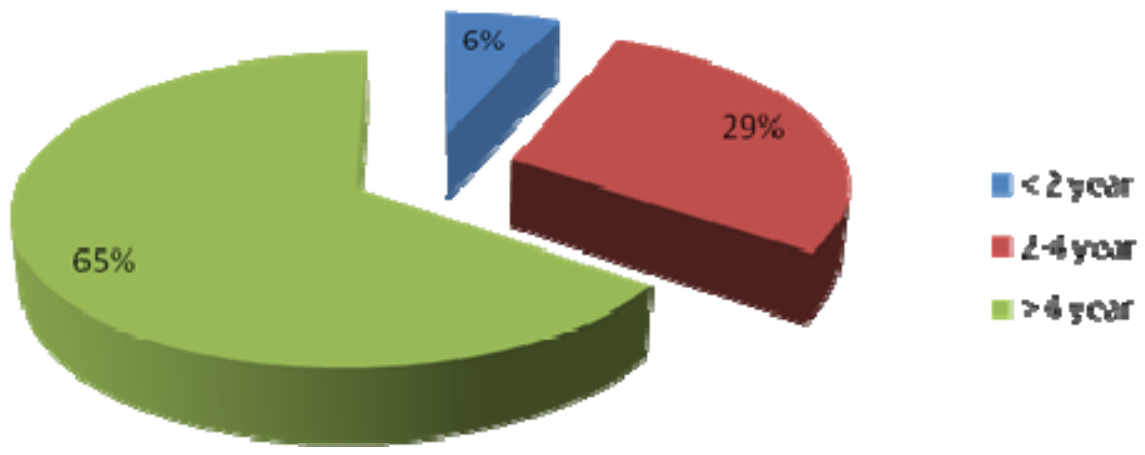

Figure 2. Percentage of the students based on their experience using the Internet

Briefly, Table 2 shows the students importance level of each attribute. At a glance, traditional learning style is dominant the upper rank whereas e-learning attribute fallen into last rank. In other words, students prefer traditional learning style compared to e-learning. The implementation of Wiley-Plus in their courses does not change students' perception toward learning style. Specifically, read text or reference book and read lecture shows the most preference learning style to the students with 3.63 points. It followed by read their own exercises and read tutorial with mean 3.94 and 3.74, respectively. Students still firmly believe that traditional way of learning is more important than e-learning. It can be prove by result that represents in Table 2. It shows that 
students feel least important to using mathematical applications in the Wiley-Plus (5.67 points) or any related mathematics website (5.89). Basically, we know that students experienced using internet but they are not considered e-learning has the same priority with traditional learning. Based on the Table 1, students are not favourable with the e-learning attribute.

In other perspective, students prefer to be alone rather than in group during learning process. The result indicates that individual learning style fall in upper rank. In contrast, group learning style fall in middle rank which asked the tutor is preferable (4.42 points). It followed by asked lecturer (4.17 points) and discussions with friends (4.13 points).

Table 1. Mean values of students' perception towards approach used

\begin{tabular}{lll}
\hline Rank & The approach used & Mean \\
\hline 1 & Read text or reference book & 3.63 \\
2 & Read lecture notes & 3.63 \\
3 & Read their own exercises & 3.94 \\
4 & Read tutorial & 3.74 \\
5 & Discussion with friends & 4.13 \\
6 & Asked lecturer & 4.17 \\
7 & Asked Tutor & 4.42 \\
8 & using mathematical applications in the Wiley-PLUS & 5.67 \\
9 & e-learning (using any web sites related to mathematics) & 5.89 \\
\hline
\end{tabular}

(Scale: $1=$ most importance $10=$ least importance)

\section{Conclusion}

This research revealed that students in Faculty Engineering and Built Environment (FKAB) prefer to study in traditional learning style rather than through e-learning. Specifically, students prefer study as an individual as compared to group in learning mathematics. This implies, the importance of e-learning are not move parallel with traditional learning style. Thus, more actions needed to improve the e-learning system so that e-learning can help students in various ways.

\section{Acknowledgements}

The authors would like to thank Universiti Kebangsaan Malaysia for providing the research grant (PTS-2012-016) and (PTS-2012-091).

The author also gratefully acknowledge to the Centre for Engineering Education Research, Universiti Kebangsaan Malaysia in the effort of improving the quality of teaching and learning in engineering education and appreciate the cooperative among the project partners.

\section{References}

Albano, G. (2005). Mathematics and e-learning: Students' beliefs and waits. Proceedings of the Commission Internationale pour l'Étude et l'Amélioration de l'Enseignement des Mathématiques, 153-157.

Albano, G., \& Ferrari, P. L. (2008). Integrating technology and research in mathematics education: The case of e-learning. Advances in E-learning: Experiences and Methodologies, 132-148. http://dx.doi.org/10.4018/978-1-59904-756-0.ch008

Azizan, F. Z. (2010). Blended learning in higher education institution in Malaysia. Proceedings of Regional Conference on Knowledge Integration in ICT, 454-466.

Borasi, R. (1990). The invisible hand operating on mathematics instruction: Students' conceptions and expectations. In T. J. Cooney (Ed.), Teaching and Learning Mathematics in the 1990s (NCTM Yearbook) (pp. 174-182). Reston: NCTM.

Bringslid, O. (2002). Mathematical e-learning using interactive mathematics on the Web. European Journal Of Engineering Education, 27(3), 249-255. http://dx.doi.org/10.1080/03043790210141564 
Che-Ani, A. I., Tawil, N. M., Abdullah, N. A. G., Tahir, M. M., \& Zaharim, A. Learning behavior in using portal system for architecture's students in the research methodology course. Research Journal of Applied Sciences, 4.

David, C., Ginev, D., Kohlhase, M., \& Corneli, J. (2010). eMath 3.0: Building blocks for a social and semantic Web for online mathematics \& E-Learning.

Hisham, D., Mustafa, C. S., \& Bakar, H. A. (2006). Moving forward with blended learning as a pedagogical alternative to traditional classroom learning. Malaysian online Journal of Instructional Technology (MOJIT), $3(1), 11-18$.

Lim, D. H., Morris, M. L., \& Kupritz, V. W. (2006). “Online vs. blended learning: Differences in instructional outcomes and learner satisfaction". Retrieved from http://eric.ed.gov

Mandic, D. (2010). Knowledge based multimedia system for teacher's education. Proceedings of the $9^{\text {th }}$ WSEAS International Conference on Artificial Intelligence, Knowledge Engineering and Data Bases, February 20-22, 2010, University of Cambridge, pp. 221-225.

Pais, C., Pires, V., Amaral, R., Amaral, J., Martins, J., Luz, C., \& Dias, O. P. (2004, May). A strategy to improve engineering teaching process based on an e-learning approach. Information Technology Based Higher Education and Training, 2004. ITHET 2004. Proceedings of the FIfth International Conference on (pp. 227-230). IEEE.

Rasila, A., Havola, L., Majander, H., \& Malinen, J. (2010). Automatic assessment in engineering mathematics: evaluation of the impact. Research paper, ITK Tutkijatapaaminen.

Razali, N., Tawil, N. M., Zainuri, N. A., Zaharim, A., Bahaludin, H., \& Albashah, N. L. S. (2010). E-learning in vector calculus. Kongres Pengajaran dan Pembelajaran 2010, pp. 13-18.

Tawil, N. M., Ismail, N. A., Asshaari, I., Osman, H., Nopiah, Z. M., \& Zaharim, A. (2012). Comparing lecture and e-learning as learning process in mathematics and statistics courses for engineering students in Universiti Kebangsaan Malaysia. Procedia-Social and Behavioral Sciences, 60, 420-425. http://dx.doi.org/10.1016/j.sbspro.2012.09.400

Tawil, N. M., Ismail, N. A., Asshaari, I., Osman, H., Nopiah, Z. M., \& Zaharim, A. (2012). Learning process in mathematics and statistics courses towards engineering students: E-learning or traditional method? Asian Social Science, 8(16), 128. http://dx.doi.org/10.5539/ass.v8n16p128

Tawil, N. M., Zaharim, A., Ariff, F. H. M., Ismail, N. A., \& Osman, M. H. (2010). Implementing e-learning in mathematics engineering for better understanding. Proceedings of the 9th WSEAS international conference on Artificial intelligence, knowledge engineering and data bases (pp. 250-253). World Scientific and Engineering Academy and Society (WSEAS).

Yushau, B. (2006). The Effects of Blended E-learning on Mathematics and Computer Attitudes in Pre-calculus Algebra. The Montana Mathematics Enthusiast, 3(2), 176-183. 